\title{
Pembelajaran CTL Sebagai Strategi Peningkatan General Life Skill Khususnya Kecakapan Berpikir Rasional Dan Kecakapan Berpikir Sosial
}

\author{
Hermin Lempang \\ SMP Negeri 9 Kabupaten Sorong \\ email:
}

\begin{abstract}
This research is a classroom research action which contains of three cycle. Every cycle consist of four steps such as 1) planning, 2) action, 3) observing, 4) reflection. The subject of this research is the students of class VIIIA SMP Negeri 9 Sorong Regency with Contextual Teaching and Learning aplicated to them. With applied CTL is a learning which can improve the ability of rational thinking and students social ability. The development of result study obtained from the questionnaire of rational thinking and social ability, the observation paper of learning process, observation of asking and questioning on an interview, learning logs, teacher's journal, and result of the test. The result of this action showed that in every cycle, the ability of rational thinking and social being increased. The rational thinking and social ability in the first condition is $10 \%$, and $10 \%$, and in the end of the research become $80 \%$ and $90 \%$. The total of accomplishment of rational and social thinking ability in the end of this research is $85 \%$ and this value is pass the standard estimate that is $75 \%$, so learning process by using CTL proved can improve the general life skill in the rational and social thinking ability. Students responses pleasant qualitatively and the material of the subject is understandable. The result of study increased from $25 \%$ become $90 \%$, and the teacher's performance also increased from $75 \%$ become $90 \%$
\end{abstract}

Keyword: The study of Contextual Teaching and Learning (CTL), general life skill.

\begin{abstract}
Abstrak: Penelitian ini merupakan Penelitian Tindakan Kelas yang meliputi tiga siklus. Setiap siklus terdiri atas empat tahap, yaitu 1) perencanaan, 2) tindakan, 3) pengamatan, dan 4) refleksi. Subjek penelitian adalah siswa kelas VIII B SMP Negeri 9 Kabupaten Sorong dengan penerapan pembelajaran kontekstual (Contextual Teaching and Learning). Dengan penerapan CTL adalah pembelajaran dapat meningkatkan kecakapan berpikir rasional dan kecakapan sosial siswa. Data kemajuan hasil tindakan diperoleh dari angket kecakapan berpikir rasional kecakapan sosial, lembar observasi KBM, observasi tanya jawab wawancara, learning logs, jurnal guru, dan hasil ulangan. Hasil tindakan menunjukkan pada tiap-tiap siklus kecakapan berpikir rasional dan kecakapan sosial meningkat. Kecakapan berpikir rasional dan kecakapan sosial siswa pada kondisi awal sebesar $10 \%$, dan $10 \%$ sedangkan pada akhir penelitian mencapai $80 \%$ dan $90 \%$. Total pencapaian kecakapan berpikir rasional dan kecakapan berpikir sosial pada akhir penelitian sebesar $85 \%$ melampaui batas perkiraan yaitu sebesar $75 \%$, dengan demikian
\end{abstract}


pembelajaran CTL teruji yaitu dapat meningkatkan general life skill pada kecakapan berpikir rasional dan kecakapan berpikir sosial. Respon siswa secara kualitatif menyenangkan dan materi mudah dipahami. Hasil ketuntasan belajar meningkat dari $25 \%$ menjadi $90 \%$ sedangkan kinerja guru juga meningkat dari $75 \%$ menjadi $95 \%$.

Kata kunci : Pembelajaran Contextual Teaching and Learning (CTL), general life skill

\section{Pendahuluan}

Pembelajaran Pendidikan Pancasila dan Kewarganegaraan (PPKn) seringkali hanya bersifat verbal tidak pernah dikaitkan dengan kehidupan nyata, siswa lebih sering hanya menjadi pendengar tanpa dilibatkan untuk berpikir secara kritis yaitu untuk menggali dan menemukan informasi, mengambil keputusan dan memcahkan masalah secara kreatif, padahal Pendidikan Pancasila dan Kewarganegaraan (PPKn) adalah pelajaran yang fungsinya untuk mempersiapkan proses alih generasi muda yang memiliki kecakapan hidup agar dapat menghadapi masa depan yang sarat dengan tantangan. Akibatnya pembelajaran Pendidikan Pancasila dan Kewarganegaraan (PPKn) hanya sebagai wahana penyampaian fakta-fakta yang menyebabkan siswa tidak memiliki kecakapan berpikir rasional dan kecakapan sosial yang baik atau kecakapan berpikir dan kecakapan sosial siswa rendah.

Ada beberapa faktor yang menyebabkan rendahnya kecakapan berpikir rasional dan kecakapan sosial siswa rendah antara lain guru kurang mampu memilih strategi pembelajaran yang tepat. Dari macam-macam model pembelajaran, Contextual Teaching and Learning (CTL) adalah strategi yang dapat dipercayai dapat meningkatkan kecakapan berpikir rasional dan kecakapan sosial siswa karena pembelajaran Contextual Teaching and Learning (CTL) menantang siswa untuk berpikir secara kritis, membangun pengetahuan sendiri, menarik kesimpulan sendiri dan Contextual Teaching and Learning (CTL) juga dapat meluaskan siswa secara aktif belajar bersama dengan siswa lain.

Berdasarkan latar belakang tersebut maka fokus penelitian tindakan kelas ini adalah meningkatkan kecakapan hidup (general life skill) khususnya pada kecakapan berpikir rasional dan kecakapan sosial siswa di kelas VIII A SMP Negeri 9 Kabupaten Sorong semester satu tahun pelajaran 2014/2015.

Manfaat penelitian bagi guru adalah meningkatkan pengetahuan dan keterampilan dalam mengggunakan strategi belajar, meningkatkan pengelolaan pembelajaran Pendidikan Pancasila dan Kewarganegaraan (PPKn), mengembangkan sikap ilmiah dan merangsang guru untuk berkreasi.

Manfaat penelitian bagi sekolah adalah menciptakan suasana kelas yang kondusif dan memberi dampak positif bagi guru lain untuk berkreasi mengelolaan Kegiatan Belajar Mengajar.

\section{Metode Penelitian}

Penelitian tindakan kelas ini dilaksanakan di SMP Negeri 9 Kabupaten Sorong pada bulan Februari sampai Juli 2015. Subyek penelitian ini adalah kelas VIII A yang berjumlah 20 siswa terdiri dari 9 laki-laki dan 11 perempuan. 


\section{a. Desain Penelitian}

Untuk memastikan rendahnya kecakapan berpikir rasional dan kecakapan sosial siswa kelas VIII B, dilakukan observasi dalam pelaksanaan pembelajaran mata pelajaran Pendidikan Pancasila dan Kewarganegaraan (PPKn) dan penyebaran angket. Setelah dilakukan kajian yang didasari sharing ide antara guru kolabolator dan kajian teoritis, maka ditetapkan tindakan untuk meningkatkan kecakapan berpikir rasional dan kecakapan sosial dengan menerapkan pendekatan pembelajaran Contextual Teaching and Learning (CTL). Kegiatan ini merupakan pra desain penelitian, sedang post desain diperoleh dari analisis hasil siklus. Selisih hasil pra desain dengan hasil siklus I, II, III, menunjukkan peningkatan kecakapan berpikir rasional dan kecakapan sosial. Proses Kegiatan Belajar Mengajar menggunakan pendekatan Contextual Teaching and Learning (CTL) dengan metode observasi melakukan kunjungan pada suatu obyek, penugasan diskusi model jigsaw, presentasi.

\section{b. Jenis Instrumen}

Untuk mendapatkan data kuantitatif dan kualitatif diukur dengan menggunakan instrumen yang berupa :

1) Lembar observasi Kegiatan Belajar Mengajar yang meliputi lembar kecakapan berpikir rasional dan kecakapan sosial, lembar respon siswa. Lembar kinerja guru digunakan untuk memperoleh gambaran jumlah siswa yang menerapkan kecakapan berpikir rasional dan kecakapan sosial. Data diambil setiap langkah pembelajaran dengan memberi tanda lurus pada guru kolabor.

2) Lembar observasi tanya jawab digunakan untuk merekam semua pertanyaan dan jawaban.

3) Angket kecakapan berpikir rasional, kecakapan sosial dan kinerja guru diisi oleh siswa, untuk merekam kecakapan berpikir dan kecakapan sosial.

4) Pedoman wawancara siswa digunakan untuk mendapat data kualitatif berupa tanggapan dari siswa.

5) Pedoman wawancara guru kolabor digunakan untk merekam jawaban guru peneliti terhadap proses Kegiatan Belajar Mengajar.

6) Learning $\log s$ adalah catatan refleksi tentang keterlibatan siswa dalam Kegiatan Belajar Mengajar.

7) Jurnal guru berisi catatan refleksi fenomena kelas dibuat oleh guru

8) Portofolio instrumen yang berisi hasil siswa setelah diberi tindakan dan dokumentasi Kegiatan Belajar Mengajar.

Sebelum digunakan, instrumen tersebut divalidasi dengan menggunakan face validity dan try out, triangulasi validitas

\section{c. Langkah Penelitian}

Penelitian dilaksanakan 3 siklus, setiap siklus terdiri dari 2 pertemuan, waktu yang diperlukan 2 jam pelajaran @ 40 menit. Dengan pokok kegiatan dalam tindakan meliputi : planning (perencanaan), tindakan (acting), pengumpulan data (observing), dan perenungan (reflecting).

\section{d. Pelaksanaan}

Siklus I, meliputi:

Perencanaan (Planning) :

1) Identifikasi masalah dan penyebab identifikasi masalah

Dari hasil observasi dalam pembelajaran Pendidikan Pancasila dan Kewarganegaraan (PPKn) ditemukan indikasi siswa kelas VIII B SMP Negeri 9 Kabupaten Sorong memiliki kecakapan berpikir rasional dan kecakapan 
sosial rendah yang disebabkan karena guru belum menyiapkan pembelajaran yang menarik dan bervariasi

2) Intervensi yang diterapkan adalah pembelajaran Contextual Teaching and Learning (CTL) dengan konsep :

a) Proses pembuatan Anggaran Dasar dan Anggaran Rumah Tangga Koperasi.

b) Mentaati peraturan perundang-undangan nasional.

c) Mengidentifikasi kasus pelanggaran peraturan lalu lintas.

Perencanaan dalam siklus ini meliputi:

a) Menyusun Rencana Pelaksanaan Pembelajaran (RPP).

b) Mengidentifikasi pokok bahasan dan sub pokok bahasan yang diberi tindakan Contextual Teaching and Learning (CTL)

c) Membuat LKS dengan pendekatan Contextual Teaching and Learning (CTL)

d) Menyiapkan kunjungan ke objek pembelajaran

e) Menyusun soal ulangan

f) Menyiapkan instrumen pemantauan

\section{Penerapan tindakan (acting)}

Pelaksanaan Kegiatan Belajar Mengajar sesuai dengan rencana pembelajaran dengan langkah :

a) Pertemuan I

Mengadakan kunjungan ke Koperasi Handayani dalam rangka menggali informasi sesuai dengan topik permasalahan masing-masing kelompok dan membuat laporan sesuai dengan format yang telah disediakan

b) Pertemuan II melaksanakan diskusi dengan pembelajaran kooperatif tipe jig saw

Guru memberi penjelasan terhadap pelaksanaan diskusi berbentuk kelompok kooperatif yang terdiri 4 kelompok dengan anggota 5 orang. Setiap siswa mendapat pertanyaan yang berbeda, siswa nomor absen 01 mendapat pertanyaan nomor 1 begitu seterusnya sampai siswa nomor absen 05. Selanjutnya yang mendapat soal nomor yang sama membuat kelompok dan mengerjakan tugasnya. Setelah selesai, kelompok ahli ini kembali pada kelompok semula untuk menularkan hasil pekerjaannya kepada kelompok masing-masing. Selanjutnya presentasi di depan kelas dan memberi kesempatan pada kelompok lain untuk bertanya, pelurusan hasil, menarik kesimpulan dan diakhiri dengan ulangan harian.

\section{Pengumpulan data (observing)}

Pengumpulan data pembelajaran dilaksanakan secara kolaborasi dengan guru lain dengan menggunakan alat monitoring berupa instrumen lembar observasi Kegiatan Belajar Mengajar yang berupa lembar kecakapan berpikir rasional dan kecakapan berpikir sosial, lembar respon siswa, lembar kinerja guru. Data tentang kemampuan berpikir siswa diperoleh dari lembar observasi Kegiatan Belajar Mengajar, lembar observasi tanya jawab, tingkat kecakapan berpikir rasional dan kecakapan sosial, kinerja guru dan learning logs siswa yang diisi siswa pada akhir Kegiatan Belajar Mengajar dan hasil belajar diperoleh dari ulangan. 


\section{Refleksi (Reflecting)}

Kegiatan ini meliputi penganalisaan data kuantitatif dan kualitatif didasari observasi instrumen yang ada hasilnya, digunakan untuk pertimbangan pada siklus selanjutnya.

\section{Siklus II}

Alokasi waktu yang diperlukan 2 minggu dengan materi "mentaati perundangundangan nasional". Proses pembelajaran terdiri dari 2 kegiatan. Kegiatan I mengadakan kunjungan ke Polsek Salawati, sedangkan kegiatan II melaksanakan diskusi model jigsaw.

a. Perencanaan ulang (replanning)

Pada tahap ini meliputi : 1) identifikasi masalah siklus I dan rencana perbaikan; 2) Menyusun rencana pembelajaran, LKS, Contextual Teaching and Learning (CTL) dan petunjuk guru; 3) intervensi semua dengan siklus I namun perlu peningkatan kegiatan pencapaian kecakapan berpikir rasional dan kecakapan berpikir sosial; 4) Menyusun ulangan harian.

b. Pelaksanaan (acting)

Proses pembelajaran sama dengan siklus I

c. Pengumpulan data (observing)

Langkah-langkanya sama dengan siklus I

d. Refleksi (reflecting)

e. Kegiatan refleksi dilakukan sama dengan siklus I. Maksud kegiatan ini untuk mengetahui kekurangan pada siklus II dan untuk menentukan tindak lanjut berikutnya.

\section{Siklus III}

Alokasi waktu dan proses pembelajaran sama dengan siklus II. Pokok bahasan yang diitervensi adalah "mengidentifikasi kasus palanggaran peraturan lalu lintas" pada kegiatan I mengadakan observasi langsung ke Polsek Salawati membandingkan dengan teori yang ada, menarik kesimpulan, membuat laporan. Kegiatan II melaksanakan diskusi dengan pembelajaran kooperatif versi jig saw yang diakhiri dengan ulangan.

Tahap pelaksanaan siklus III

a. Pelaksanaan ulang (replanning)

Kegiatan ini meliputi : 1) Identifikasi masalah siklus I dan rencana perbaikan;

2) Penyempurnaan Rencana Pembelajaran, LKS; 3) Intervensi langkahnya sama dengan siklus II.

b. Pelaksanaan (acting)

Kegiatan sama dengan siklus II

c. Pengumpulan data (observing)

Langkah-langkanya sama dengan siklus II

d. Refleksi (reflecting)

Tindakan tahap ini dengan mengulas secara kritis untuk mengetahui pengaruh intervensi pada perubahan. 


\section{Hasil dan Pembahasan}

a. Cara penilaian/pemantauan/monitoring

Monitoring dilakukan untuk mengamati dengan mencatat proses pembelajaran dan mecatat dinamika Kegiatan Belajar Mengajar dalam upaya meningkatkan kecakapan berpikir rasional dan kecakapan sosial dapat mencapai target atau tidak.

Pelaksanaan monitoring dilaksanakan kolabor dan peneliti pada setiap Kegiatan Belajar Mengajar berlangsung dua kali selama proses penelitian dengan sasaran dalam Kegiatan Belajar Mengajar di kelas maupun di luar kelas. Dengan menggunakan instrumen yang telah dipersiapkan, lembar observasi tanya-jawab. Setelah selesai siswa diberi angket kecakapan berpikir rasional dan kecakapan sosial dapat mencapai target atau tidak.

Pelaksanaan monitoring dilaksanakan kolabor dan peneliti pada setiap Kegiatan Belajar Mengajar berlangsung dua kali selama proses penelitian dengan sasaran dalam Kegiatan Belajar Mengajar di kelas maupun di luar kelas. Dengan menggunakan instrumen yang telah dipersiapkan, lembar observasi tanya-jawab. Setelah selesai siswa diberi angket kecakapan berpikir rasional, kecakapan berpikir sosial, guru dan learning logs untuk diisi siswa kemudian dikumpulkan. Instrumen ini untuk proses Kegiatan Belajar Mengajar di kelas, sedang kegiatan wawancara dilakukan di luar jam pelajaran yang waktunya mendekati Kegiatan Belajar Mengajar.

b. Analisa Hasil Refleksi

Peneliti dan kolabor menganalisa data hasil penelitian dan analisa deskriptif, data yang dianalisa adalah data kualitatif kecakapan berpikir rasional dan kecakapan berpikir sosial siswa, data kualitatif siswa, data kualitatif guru, deskriptif siswa, learning logs, jurnal guru, wawancara.

Merekap rata-rata pencapaian kecakapan berpikir rasional dan kecakapan berpikir sosial siswa dalam siklus I, II, III hasilnya dibandingkan dengan kondisi awal dan target yang ditetapkan. Kondisi awal ke siklus I, dari siklus I ke siklus II, dari siklus II ke siklus III terdapat kenaikan, maka diputuskan kecakapan berpikir rasional dan kecakapan berpikir sosial siswa naik. Begitu juga sebaliknya, jika hasil siklus I, siklus II, siklus III dibanding dengan target tercapai maka diputuskan target tercapai.

c. Hasil penelitian

Setelah dilakukan tindakan dengan model pembelajaran Contextual Teaching and Learning (CTL) hasilnya sebagai berikut : 
Grafik 1. Pencapaian Total Kecakapan Sosial

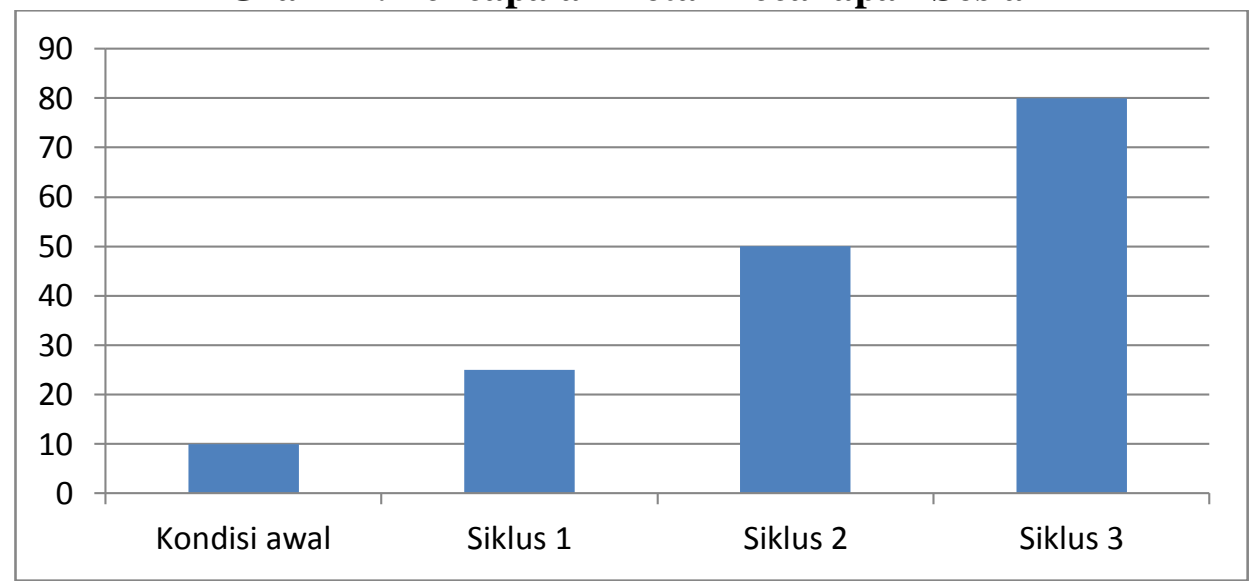

Grafik 2. Pencapaian Total Kecakapan Berpikir Rasional

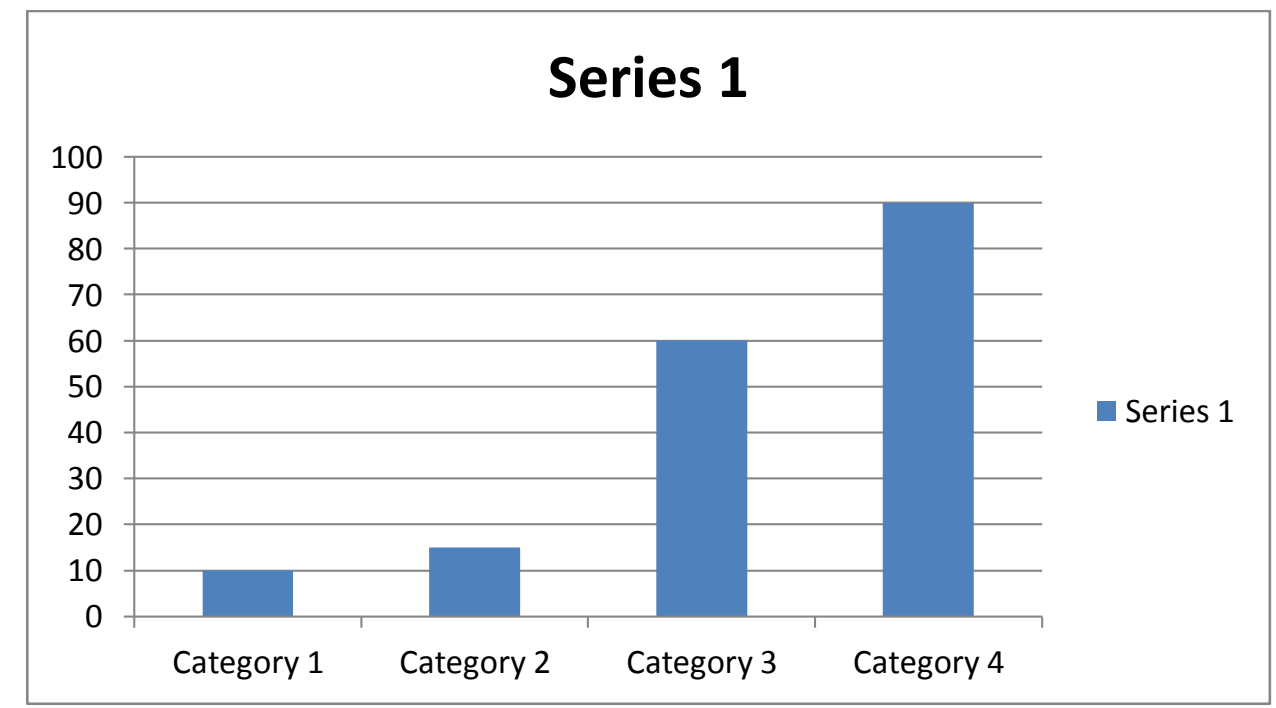

Siklus I

Pada siklus ini guru membawa siswa untuk mengadakan observasi ke Koperasi Handayani SMPN 9 Kabupaten Sorong untuk mengungkap permasalahan perumusan pembuatan Anggaran Dasar dan Anggaran Rumah Tngga Koperasi. Pelaksanaan observasi ini berlangsung dengan suasana yang sangat komunikatif, siswa banyak memberikan pertanyaan kepada narasumber walaupun pertanyaanya masih pada tingkat pertanyaan rendah. Hal ini menunjukkan indikasi adanya peningkatan kemampuan berpikir rasional.

Berdasarkan pengalaman kolaborasi juga menunjukkan bahwa suasana belajar menyenangkan. Kekurangan pada siklus ini adalah kerjasama belum tampak dengan baik. Untuk itu secara kolaborasi disepakati adanya perbaikan pada siklus berikutnya, yaitu : memberikan penjelasan lebih detail tentang pendekatan pembelajaran Contextual Teaching and Learning (CTL), mengarahkan siswa untuk bertanya pada tingkatan yang lebih tinggi melalui pertanyaan yang diawali dengan 
kata "mengapa, bagaimana, jelaskan" dan meningkatkan kerjasama dengan teman lain dalam kelompoknya.

\section{Siklus II}

Pada siklus II siswa mengunjungi Satlantas Polsek Salawati dengan tujuan agar siswa memiliki kesadaran menaati peraturan lalu lintas. Proses pembelajaran berlangsung lebih menarik dan terarah, hal ini disebabkan siswa sudah memiliki pengalaman pembelajaran Contextual Teaching and Learning (CTL) pada siklus I, pertanyaan-pertanyaan yang diajukan meningkat kualitasnya, siswa mulai menggunakan pertanyaan tingkat tinggi, kemampuan siswa untuk membuat kesimpulan dan bekerjasama juga meningkat. Dari uraian tersebut menunjukkan indikasi adanya peningkatan pada sebagian besar indikator kecakapan berpikir rasional dan kecakapan sosial.

Berdasarkan hasil wawancara guru/kolabor, siswa dan learning logs menunjukan bahwa pembelajaran Contextual Teaching and Learning (CTL) dalam siklus ini sangat menyenangkan, pemahaman terhadap materi lebih mudah, karena siswa secara langsung terlibat untuk menggali informasi sendiri.

Pada tahap refleksi II secara kolaborasi disepakati adanya perbaikanperbaikan agar tetap memberikan penjelasan pada siswa mengenai sasaran yang hendak dicapai dalam pembelajaran Contextual Teaching and Learning (CTL), meningkatkan pola kerjasama, meningkatkan kualitas jenis pertanyaan, menyempurnakan dalam membuat kesimpulan agar lebih sistematis.

\section{Siklus III}

Pada siklus ini siswa mengadakan observasi pada Polsek Salawati yang bertujuan dapat mengidentifikasi kasus pelanggaran peraturan lalu lintas dan penanggulangannya. Seperti pada siklus I dan siklus II, setelah siswa mengadakan observasi selanjutnya melaksanakan diskusi kelas. Pada pelaksanaan diskusi, suasana pembelajaran semakin komunikatif, kualitas pertanyaan dan jawaban siswa pada tingkat pertanyaan/ jawaban yang tinggi. Karena siswa yang antusias, pembelajaran ini hingga menggunakan waktu istirahat dan siswa mengatakan "tidak apa-apa bu, sedang asyik", juga ada siswa yang menanyakan "besok minggu depan kita membahas apa bu?". Dari ungkapan siswa tersebut, memberi indikasi bahwa pembelajaran Contextual Teaching and Learning (CTL) membangkitkan minat siswa yang akan berdampak pada peningkatan hasil belajar. Hasil kolaborasi menyatakan bahwa Kegiatan Belajar Mengajar berlangsung sangat menyenangkan, semua siswa terlibat aktif terhadap pemahaman materi. Pada siklus III ini terjadi peningkatan pada semua aspek yang diamati yang disebabkan karena semakin pahamnya siswa dan guru terhadap pelaksanaan Contextual Teaching and Learning (CTL). Rata-rata peningkatan kecakapan berpikir rasional dan berpikir sosial siswa menjadi $80 \%$ dan 90\%. Dari kodisi awal 10\% dan 10\%. Jadi total pencapaian kecakapan berpikir rasional dan kecakapan berpikir sosial menjadi 85\%. Hasil ini melampaui target yang ingin dicapai yaitu $75 \%$. 


\section{Kesimpulan dan Saran \\ a. Kesimpulan}

Berdasarkan hasil penelitian tindakan kelas, dapat dikemukakan simpulan sebagai berikut :

1) Model pembelajaran Contextual Teaching Learning (CTL) yang dilaksanakan di kelas VIII B SMP Negeri 9 Kabupaten Sorong tahun pelajaran 2014/2015 dapat meningkatkan general life skill, kususnya pada kecakapan berpikir rasional dan kecakapan sosial. Sebelum menggunakan Contextual Teaching and Learning (CTL), kecakapan berpikir rasional siswa adalah 10\%, setelah diadakan tindakan dan pembelajaran Contextual Teaching and Learning (CTL) menjadi 80\%, berarti mengalami peningkatan $70 \%$.

2) Kecakapan sosial siswa sebelum menggunakan Contextual Teaching and Learning (CTL) 10\%, setelah menggunakan Contextual Teaching and Learning (CTL) menjadi $90 \%$ berarti mengalami peningkatan sebesar $80 \%$. Jadi total peningkatan kecakapan berpikir rasional dan kecakapan sosial yaitu $85 \%$ melampaui target yang ditetapkan yaitu $75 \%$.

3) Model pembelajaran Contextual Teaching and Learning (CTL) tidak hanya berdampak positif bagi siswa saja tetapi juga dapat meningkatkan kinerja guru.

4) Guru peneliti memperoleh banyak pengalaman dan pengetahuan baru tentang penelitian tindakan kelas dan menambah perbendaharaan model pembelajaran.

\section{b. Saran}

Berdasarkan hasil penelitian di atas, maka peneliti dapat memberikan saran sebagai berikut :

1) Hal yang harus diperhatikan apabila akan menerapkan pembelajaran Contextual Teaching and Learning (CTL) adalah dalam melakukan pemilihan materi dapat menggunakan pendekatan Contextual Teaching and Learning (CTL) dan menyusun perencanaan pembelajaran perlu mendapat perhatian yang khusus agar dapat menghasilkan rencana pembelajaran yang baik.

2) Banyak melakukan kolaborasi, semakin banyak guru yang diajak berkolaborasi akan dapat meringankan pekerjaan guru.

\section{Daftar Pustaka}

Aim Abdulkarim. 2003. PPKn 2 untuk SMP Kelas VIII. Bandung : Grasindo

Andreas, Priyono. 1999. Penulisan Proposal Penelitian Clasroom Base Action Research. Semarang : Departemen Pendidikan dan Kebudayaan, Kanwil Depdikbud Propinsi Jawa Tengah.

Andreas Priyono. 2000. Pengumpulan Data Penelitian Tindakan Kelas : Buletin MAW Jawa Tengah. Semarang : Departemen Pendidikan dan Kebudayaan, Kanwil Depdikbud Propinsi Jawa Tengah.

Anonim. 1994. Kurikulum Sekolah Lanjutan Pertama : Garis-garis Besar Program Pengajaran. Jakarta : Departemen Pendidikan Dasar dan Menengah. Direktorat Pendidikan Menengah Umum.

AT. Sugeng Priyanto. 2003. Life Skill. Universitas Negeri Semarang.

Diklat Instruktur PPKn SLTP (2W2). Penilaian Pembelajaran PPKn SLTP. 
Staf Center for Civic Education Indonesia, Edisi 2 (2003). Buku Panduan Guru "Kami Bangsa Indonesia".

Sungkono. 2003. Contextual Teaching and Learning (CTL). Departemen Pendidikan Nasional : Dirjen Pendidikan Dasar dan Menengah. Direktorat Pendidikan Lanjutan Pertama. 